\title{
OVERVIEW OF DEVELOPMENTS OF CEREAL HARVESTER FLEET IN ESTONIA
}

\author{
Juri Olt, Risto Ilves, Arne Kuut \\ Estonian University of Life Sciences, Estonia \\ jyri.olt@emu.ee
}

\begin{abstract}
Tractors and cereal harvesters are technical means, which have a strong influence on the technological development trends of plant production. The aim of this article was to provide an overview of the developments of the cereal harvester fleet in Estonia between 2010 and 2017. For this purpose, the data from the Statistics Estonia, particularly the Traffic Register as on 31 December 2017 was used. The article points out changes in the number of agricultural holdings by the size class of the growing area for cereals; the number of cereal harvesters, including the number of new harvesters sold year-by-year and the preferences of agricultural holdings for cereal harvesters and distribution of new cereal harvesters by the manufacturer during the period. It becomes evident that during the last decade the cereal harvester fleet has changed a lot in Estonia. Harvesters dating back to the Soviet time have gone out of use and new, more well-known harvester brands have replaced them. The most sold harvester brand in Estonia is Claas, but New Holland, John Deere, Case, Fendt, Sampo, Massey Ferguson, Laverda, etc. are also represented. The average engine power of a harvester has increased by $50.3 \%$ and the average width of the header has increased by $36.4 \%$. The information from the cereal harvester's on-board computer is being used increasingly for guiding the work of the cereal harvester fleet in order to optimise the harvesting costs.
\end{abstract}

Keywords: cereal harvester, productivity, development trends, harvester fleet.

\section{Introduction}

Similarly to tractors, cereal harvesters are technical means, which have a strong influence on the technological development trends of plant production. Several methods are known for the selection of cereal harvesters and development of the harvester fleet and these methods have been addressed by several researchers [1-13]. For example, the aim of the method of Bulgakov et al. [14] is determination of the capacity and technical composition of the harvester fleet in order to ensure that all harvesting tasks are performed according to the structure of growing cereals, growing area's size, shape and agrotechnically optimal times and with optimal material and working time costs. The use of such a model requires a lot of source data, including the structure of growing cereals, weather changes and other factors. Often development of the fleet may be influenced by the factors such as brand loyalty, location of machine sales or service centres, i.e., their distance from the customer, which may result in selection of the closest in order to get help quickly in case of a fault during the harvest period. The fleets of tractors and cereal harvesters (mostly the number of machines and their capacities) has changed as a result of development of the technology $[15 ; 16]$, but these have also changed due to the socio-economical changes of land [17-19]. Since the year 1965, when the record number of cereal harvesters (more than 60,000 machines) were manufactured and taken into use in Western Europe, the general trend has been that the engine power and productivity have increased year-by-year and, therefore, their annual sales numbers have decreased. Here arises the question of whether this trend characterises the development of the agricultural machine and tractor fleet in Estonia?

According to the conditions of agricultural production, the Baltic and the Nordic countries lie in similar climatic conditions and there are no other significant differences in the traditions of agricultural production. At the same time, their agricultural production and technological level has been very different. Agriculture of the Nordic countries has developed in stable conditions and longterm investments have been made into the development of the fleet. On the other hand, Estonia, Latvia and Lithuania have performed very radical agricultural reforms after the restauration of independence in 1991. Before 1991, Estonia had large-scale agricultural production, mostly in the form of collective farms and state farms, which partly dissolved, broke into pieces and changed the ownership form after the year 1991. For example, 10 years after the restoration of independence (in 2001), the number of households involved in the production of cereals was 20,542 [20], whereat the average size of the growing area for cereals per one household was 13.3 ha; but by the year 2016, the number had decreased to 4985 households (Table 1), whereat the average size of the growing area for cereals had increased to 70.9 ha. This was a period of active mergers of households. In 2001, there were a total of 466 households, which were larger than 100 ha, and their area for growing cereals was 148,125 ha, which results in the average size of the cereal field of these households of 317.9 ha. There were no 
households with a growing area for cereals larger than 100 ha in 2001; however, in 2010, there were already 18 households with a growing area for cereals larger than 1000 ha, in 2013 there were 24 such households and 26 in 2016. In 2016, these 26 households had a growing area for cereals of 42,375 ha, whereby the average growing area had already increased to 1630 ha.

Number of agricultural households by size class of growing area for cereals during 2010-2016

\begin{tabular}{|c|c|c|c|}
\hline Growing area size class & $\mathbf{2 0 1 0}$ & $\mathbf{2 0 1 3}$ & $\mathbf{2 0 1 6}$ \\
\hline Total & 5728 & 5468 & 4985 \\
\hline $0-1$ & 704 & 577 & 477 \\
\hline $1-2$ & 628 & 482 & 353 \\
\hline $2-5$ & 1037 & 886 & 740 \\
\hline 510 & 843 & 776 & 742 \\
\hline $10-20$ & 691 & 730 & 567 \\
\hline $20-30$ & 343 & 394 & 323 \\
\hline $30-50$ & 404 & 389 & 377 \\
\hline $50-100$ & 425 & 467 & 477 \\
\hline$>100$ & 653 & 768 & 930 \\
\hline $100-300$ & 425 & 506 & 630 \\
\hline $300-500$ & 127 & 142 & 161 \\
\hline $500-1000$ & 83 & 96 & 113 \\
\hline$>1000$ & 18 & 24 & 26 \\
\hline
\end{tabular}

The tendencies were similar to those during 2001-2007 [21], but changes have taken place and continue today at an increasing speed. These changes in the number of households growing cereals and growing areas (Table 1) have had a strong influence on the development of the machine and tractor fleet, most notably the cereal harvester fleet.

As the development of the agricultural machine and tractor fleet in Estonia has already been studied [17], the aim of this study was to provide an overview of the development of the cereal harvester fleet during the following period, more precisely 2010-2017.

\section{Materials and Methods}

In order to study the dynamics of the change of the size of the cereal harvester fleet in the Republic of Estonia, mostly the data from the statistical office of Estonia [22] were used, more precisely the data on non-road vehicles (tractors, loaders, harvesters) and tractor trailers registered in the Traffic Register as on 31 December 2017 (only the data on harvesters were used), but also information collected from the sales centres of harvesters.

The traffic register provided the total number of harvesters, the number of new harvesters and the number of harvesters registered for the first time during these years. This information can be used to determine the number of the harvesters deleted from the Traffic Register.

The sales centres of machines provided the engine powers and header widths of the new harvesters sold; this information was used to determine the average parameters for the relevant years. The webpages of manufacturers provided the technical specifications of the harvesters.

\section{Results and Discussion}

The total number of cereal harvesters in 2001 was 962 ; however, by 2006 it had risen to 1235 , which, thereafter, fell drastically to 753 in 2007 , i.e. 482 physically or morally depreciated harvesters were deleted from the register, including the Soviet-era low-efficiency harvesters. This resulted in the significant decrease of the average age of the harvester fleet. The number of cereal harvesters registered in the Traffic Register during the period discussed in the article (2010-2017) has been given in Table 2.

Table 2 shows that the number of cereal harvesters in the Estonian Motor Vehicle Register has constantly increased during the last decade, whereat the percentage of harvesters registered for the first time increased until 2013. The number of harvesters registered for the first time includes, in addition 
to the new harvesters, also aftermarket harvesters from other countries, mostly Germany and Finland. In 2014, there was a significant decrease in the number of the harvesters registered for the first time in comparison with the few previous years. The percentage of new harvesters in the number of the harvesters registered for the first time was relatively high and amounted to 86-95\% (Table 3).

Table 2

Number of cereal harvesters registered in the Traffic Register during 2010-2017

\begin{tabular}{|l|c|c|c|c|c|c|c|c|}
\hline \multicolumn{1}{|c|}{ Parameter } & $\mathbf{2 0 1 0}$ & $\mathbf{2 0 1 1}$ & $\mathbf{2 0 1 2}$ & $\mathbf{2 0 1 3}$ & $\mathbf{2 0 1 4}$ & $\mathbf{2 0 1 5}$ & $\mathbf{2 0 1 6}$ & $\mathbf{2 0 1 7}$ \\
\hline $\begin{array}{l}\text { Total number of } \\
\text { harvesters }\end{array}$ & 986 & 1025 & 1132 & 1241 & 1276 & 1353 & 1423 & 1471 \\
\hline $\begin{array}{l}\text { Number of harvesters } \\
\text { registered for the first } \\
\text { time }\end{array}$ & 57 & 67 & 141 & 149 & 92 & 120 & 108 & 100 \\
\hline $\begin{array}{l}\text { Number of machines } \\
\text { deleted from the } \\
\text { Traffic Register }\end{array}$ & 12 & 28 & 34 & 40 & 57 & 43 & 38 & 52 \\
\hline $\begin{array}{l}\text { Percentage of } \\
\text { machines deleted } \\
\text { from the Traffic } \\
\text { Register }\end{array}$ & 1.2 & 2.7 & 2.9 & 3.1 & 4.3 & 3.1 & 2.6 & 3.4 \\
\hline
\end{tabular}

Information on new cereal harvesters

Table 3

\begin{tabular}{|l|c|c|c|c|c|c|c|c|}
\hline \multicolumn{1}{|c|}{ Parameter } & $\mathbf{2 0 1 0}$ & $\mathbf{2 0 1 1}$ & $\mathbf{2 0 1 2}$ & $\mathbf{2 0 1 3}$ & $\mathbf{2 0 1 4}$ & $\mathbf{2 0 1 5}$ & $\mathbf{2 0 1 6}$ & $\mathbf{2 0 1 7}$ \\
\hline $\begin{array}{l}\text { Number of new } \\
\text { harvesters }\end{array}$ & 47 & 66 & 121 & 141 & 85 & 111 & 104 & 95 \\
\hline $\begin{array}{l}\text { Average engine power } \\
\text { of new harvesters, hp }\end{array}$ & 283 & 311 & 314.0 & 314.2 & 365 & 360 & 401.1 & 425.5 \\
\hline $\begin{array}{l}\text { Average laden mass } \\
\text { of new harvesters, kg }\end{array}$ & 14443 & 15732 & 16117 & 16135 & 17344 & 17614 & 18616 & 19257 \\
\hline $\begin{array}{l}\text { Average width of the } \\
\text { header, m }\end{array}$ & 5.95 & 7.10 & 6.60 & 6.80 & 7.23 & 7.21 & 7.20 & 8.12 \\
\hline $\begin{array}{l}\text { Percentage of new } \\
\text { harvesters in the } \\
\text { number of harvesters } \\
\text { registered for the first } \\
\text { time }\end{array}$ & 86.0 & 98.5 & 85.8 & 94.6 & 92.4 & 92.5 & 96.3 & 95.0 \\
\hline $\begin{array}{l}\text { Percentage of new } \\
\text { harvesters in the total } \\
\text { harvester fleet }\end{array}$ & 4.8 & 6.4 & 10.7 & 11.4 & 6.7 & 8.2 & 7.3 & 6.5 \\
\hline
\end{tabular}

Table 3 shows that the percentage of the new harvesters in the harvester fleet is small, but the percentage of the harvesters deleted from the register is even smaller (Table 1). This refers to the fact that some of the older harvesters have been put aside as a reserve in case a technical fault should arise in the main harvester during the harvesting season, then the harvester in reserve can replace it immediately; however, this starts to have an effect on the average age of the fleet. While 843 harvesters were added to the harvester fleet during 2010-2018 and another 645 harvesters during 2002-2009, then a simplified conclusion is that currently the oldest harvester in Estonia is 16 years old.

It is surprising that when the average annual load of a harvester in 2010 was 286 ha, then the number was the same in 2016 - 286 ha. At the same time, the average engine power (Table 3) had increased along with the average laden mass and average working width of the header. Here it should be noted that the average engine power increased by $33.5 \%$, the harvester's laden mass increased by $13 \%$ and average working width of the header increased by $38 \%$ during 2010-2017. 
It becomes evident from Table 2 that the number of the harvesters deleted from the Traffic Register is smaller than the number of the new harvesters registered (Table 3) during 2010-2017, which leads to the conjecture that a larger-scale deletion of harvesters from the Traffic Register may arrive in the following years similarly to 2007, when the harvester fleet decreased by 482 harvesters.

It is also interesting to view the preferences of harvester makes in Estonia during 2010-2018. Table 4 includes the distribution of newly sold harvesters by manufacturers. The causes of such a distribution are diverse and shall not be discussed in this article.

Table 4

Distribution of new harvesters by manufacturers during 2010-2018

\begin{tabular}{|l|c|c|c|c|c|c|c|c|c|}
\hline $\begin{array}{c}\text { Harvester } \\
\text { manufacturer }\end{array}$ & $\mathbf{2 0 1 0}$ & $\mathbf{2 0 1 1}$ & $\mathbf{2 0 1 2}$ & $\mathbf{2 0 1 3}$ & $\mathbf{2 0 1 4}$ & $\mathbf{2 0 1 5}$ & $\mathbf{2 0 1 6}$ & $\mathbf{2 0 1 7}$ & $\mathbf{2 0 1 8}$ \\
\hline Case & & 2 & 6 & 4 & 4 & 3 & 5 & 5 & 1 \\
\hline Claas & 20 & 21 & 43 & 55 & 31 & 35 & 42 & 30 & 32 \\
\hline John Deere & 8 & 13 & 16 & 15 & 12 & 17 & 22 & 19 & 22 \\
\hline Fendt & 0 & 0 & 0 & 0 & 1 & 0 & 4 & 1 & 1 \\
\hline New Holland & 17 & 19 & 43 & 48 & 28 & 49 & 22 & 29 & 15 \\
\hline Laverda & 1 & 0 & & 0 & 1 & & 0 & 0 & 0 \\
\hline RSM & 1 & 8 & 8 & 4 & 1 & 2 & 1 & 2 & 1 \\
\hline Sampo & 0 & 0 & 1 & 6 & 2 & 1 & 0 & 0 & 0 \\
\hline Massey Ferguson & 0 & 0 & & 0 & 0 & & 1 & 0 & 0 \\
\hline
\end{tabular}

Until the middle of 1990, the harvester fleets in Estonia, Latvia and Lithuania mostly included Soviet harvester makes like Niva, Kolos and Don. The first foreign machines, the Sampo harvesters, were introduced in Estonia about 30 years ago, but their percentage in the harvester fleet remained low and it is still low today (Table 4). Among other harvester brands, Claas was the first one to reach the Estonian market in 1996 with its harvester Dominator 78, which had a header width of $4.5 \mathrm{~m}$. Today, Claas is the best-selling harvester brand in Estonia, followed by other famous brands such as New Holland and John Deere (Table 4).

As the average annual load for one harvester was 286 ha in 2016, the Estonian harvester fleet probably included harvesters, which did not work under full load. This is further indicated by the fact that the authors of the article had in their possession the inspection data of 197 used harvesters (some of these harvesters were aftermarket machines), which included 120 harvesters by Claas, 36 by New Holland, 23 by John Deere, 8 by Case, 1 by Fendt, 1 by Massey Ferguson, 2 by Sampo and 6 by RSM and which had worked for 1 to 14 seasons, but there were only 11 machines with an average annual load of less than 286 ha. For example, the annual loads of two harvesters Claas Lexion 780 purchased in 2016 and with the engine power of $625 \mathrm{hp}$ and header width of $12.3 \mathrm{~m}$ were 1740.56 and 1739.12 ha and the area harvested in two seasons of two harvesters Claas Lexion 780 purchased in 2015 and with the engine power of $598 \mathrm{hp}$ and header width of $10.5 \mathrm{~m}$ were 2164.84 and $2167.42 \mathrm{ha}$, which results in annual loads of ca 1082 and 1084 ha. These numbers are significantly greater than the 286 ha mentioned above.

The productivity of the harvesters has improved during the years due to the harvesters' greater engine power, wider working headers and rapidly improved technological levels during the previous years. The area productivity $W$ of a cereal harvester depends directly on the working width $B$ of the header, harvester's speed of movement $v$ on the field and the working time utilisation level $\tau$ or $W=f(B, v, \tau)$. The improved technological level means here the automation of the harvester's technological settings, which reduces the time spent on the harvester's technological settings and thereby increases the working time utilization factor and productivity. As productivity is inversely proportional to the harvesting unit cost [9], then higher productivity harvesters allow to reduce the harvesting costs.

One example on automation of technological settings. For example, the Claas Lexion 780-740 includes the following IT solutions: CEBIS, CEMOS AUTOMATIC, automatic control and TELEMATICS, where at the CEMOS AUTOMATIC functions are AUTO SLOPE, CEMOS AUTO SEPARATION, CEMOS AUTO CLEANING, AUTO CROP FLOW and CRUISE PILOT. In addition 
to the abovementioned, the harvester is equipped with the GRAIN QUALITY CAMERA to inspect the quality of the harvested grain automatically.

The information obtained from the harvester's on-board computer is being used increasingly for guiding the work of the harvester fleet. The aim of this tendency is to optimise the harvesting costs. All companies producing cereal harvesters are involved in development of automation of the working process and this tendency continues at an increasing speed.

\section{Conclusions}

1. The growing areas for cereals in the agricultural households in Estonia increased by $21.7 \%$ during 2010-2017, which has resulted in the need for a higher capacity harvester fleet. The trends of the cereal harvesting fleet in Estonia in 2010-2017 were the following:

- average engine power of a cereal harvester increased by $50.3 \%$,

- average width of the header increased by $36.4 \%$,

- number of harvesters increased by $49.2 \%$.

These trends are similar to the changes in the harvester fleets of Western Europe.

2. A drastic change in the total number of the harvester fleet in Estonia is expected in the following years culminated by deletion of a large number of harvesters from the registry.

3. The harvester fleet is supplemented each year by harvesters with continuously increasing productivity.

4. Information from the harvester's on-board computer is being used increasingly for guiding the work of the harvester fleet in order to optimise the harvesting costs.

\section{References}

[1] Beneš L., Heřmánek P., Novak P. Determination of power loss of combine harvester travel gear. Agronomy Research, vol. 13(1), 2015, pp. 25-32.

[2] Bochtis D., Sørensen C.G.C., Busato P. Advances in agricultural machinery management: A review. Biosystems Engineering, vol. 126, 2014, pp. 69-81.

[3] Bochtis D., Sørensen C.G.C., Busato P. Advances in agricultural machinery management: A review. Biosystems Engineering, 2014, 126, pp. 69-81.

[4] Edwards W., Boehlje M. Machinery selection considering timeliness losses. Transactions of the American Society of Agricultural Engineers. 1980, 23 (4), pp. 810-815.

[5] Gao W.W., Donnell H.R. Optimum combine fleet selection with power-based models. Transactions of the American Society of Agricultural Engineers, 1985, 28 (2), pp. 364-368.

[6] Gunnarson C., Spörndly R., Rosenquist H., De Toro A., Hansson, P.-A. A method of estimating timeliness costs in forage harvesting illustrated using harvesting systems in Sweden. Grass and Forage Science. 2009, 64 (3), pp. 276-291.

[7] Mašek J., Novak P., Jasinskas A. Evaluation of combine harvester operation costs in different working conditions. Proceedings in Int Sci Conf Engineering for Rural Development, Jelgava, 24.-26.05.2017, Latvia University of Agriculture, 2017, pp. 1180-1185.

[8] Miu P.I., Beck F., Kutzbach H.D. Mathematical modelling of threshing and separating process in axial threshing. ASAE Paper No. 97-1063, 1997, St. Josep, MI.

[9] Olt J., Küüt K., Ilves R., Küüt A. Assessment of the harvesting costs of different combine harvester fleets. Research in Agricultural Engineering, vol. 65 (1), 2019, pp. 25-32.

[10] Prístavka M., Bujna M. Monitoring the Capability of Production Equipment in Organization. In: Acta technologica agriculturae. SUA in Nitra, 2014, pp. 39-43.

[11] Pristavka M., Krištof K., Findura P. Reliability monitoring of grain harvester. Agronomy Research, vol. 15 (3), 2017, pp. 817-829.

[12] Trollope J.R. A mathematical model of the threshing process in a conventional combine-thresher. Journal of Agricultural Engineering Research, vol. 27 (2), 1982, pp. 119-130.

[13]Zubko V., Roubik H., Zamora O., Khvorost T. Analysis and forecast of performance characteristics of combine harvesters. Agronomy Research, vol 16 (5), 2018, pp. 2294-2314. 
[14] Bulgakov V., Adamchuk V., Arak, M., Olt J. Mathematical modelling of the process of renewal of the fleet of combine harvesters. Agriculture and Agricultural Science Procedia, 2015, vol. 7, pp. 35-39.

[15] Kutzbach H.D. Trends in Power and Machinery. J. agric. Engng Res. 2000, 76, pp. 237-247.

[16] Miu P. Combine Harvesters: Theory, Modeling and Design. CRC Press, Taylor \& Francis Group. 2015, $460 \mathrm{p}$.

[17] Olt J., Traat Ü., Küüt A. Maintenance costs of intensively used self-propelled machines in agricultural companies. In: $9^{\text {th }}$ International Scientific Conference - Engineering for Rural Development, Jelgava, May 27-28. Ed. L. Malinovska, V. Osadcuks. Latvia University of Agriculture, 2010, pp. 42-48.

[18] Pawlak J, Pelizzi G., Fiala M. On the Development of Agricultural Mechanization to Ensure a Long-Term World Food Supply. Agriculture Engineering International: the CIGR Journal of Scientific Research and Development, No. 4, 2002, pp. 1- 21.

[19] Viesturs D., Kopics N. Investigation in suitability of fleet of combines for timely harvesting. Proceedings in Int Sci Conf Engineering for Rural Development, Jelgava, 25.-27.05.2016, Latvia University of Agriculture, 2016, pp. 681-686.

[20] Statistics Estonia. 2018. Agriculture. PM03. [online][16.20.2019] Available at: http://pub.stat.ee/ px-web.2001/Dialog/varval.asp?ma $=$ PM03\&lang $=2$

[21]Tamm K., Võsa T., Loko V., Kadaja J., Vettik R., Olt J. The impact of distance to the farm compound on the options for use of the cereal plot. Agricultural and Food Science, vol. 19, 2010, pp. 43-56.

[22] Statistics Estonia. 2018 Transport. TS33. [online][16.20.2019] Available at: http://andmebaas.stat.ee/Index.aspx?lang=et\&DataSetCode=TS33 